\title{
Y Kuşağı Çalışanlarında Örgütsel Sinizm: Görgül Bir Çalışma
}

DOI: 10.26466/opus.741151

\author{
* \\ Haydar Arslan* - Korhan Arun** \\ *Y.L., Tekirdağ Namık Kemal Üniversitesi, Sosyal Bilimler Enstitüsü, Tekirdağ/Türkiye \\ E-Posta: haydarslan@windowslive.com ORCID: 0000-0003-2911-9403 \\ ** Doç. Dr., Tekirdağ Namık Kemal Üniversitesi, İktisadi ve İdari Bilimler Fak., Tekirdağ/Türkiye \\ E-Posta: korhanarun@gmail.com O ORCID: 0000-0001-7494-9591
}

\begin{abstract}
$\ddot{O ̈ z}_{\mathrm{z}}$
Örgütsel sinizm; işgörenlerin çalıştıkları örgütlerine yönelik olumsuz davranıs ve tutumları olarak ifade edilmektedir. Y kuşă̆ıysa doğdukları tarihler arasında net bir uzlaşma olmamasına ră̆men 1981-2000 seneleri arasında doğmuş bireyler olarak tanımlanmaktadır. Günümüz iş dünyasının en genç ve sayı bakımından diğer kuşak bireylerinden fazla olan $Y$ kuşă̆ı bütün dünyada etkilerini göstererek çoğu örgütün iş yapış biçimlerini değiştirmeye zorlamaktadır. Sinizme sahip kişilerin seçici, tatmin düzeyi düşük, eleştiri yapan, kendisine karşı ilgi besleyen ve olumsuz bakış açısında oldukları ifade edilmesine karşın kuşaklara etkisi net olarak araştırılmamıştır. Bu araştırma ile örgütsel sinizmin $Y$ kuşağ̊ çalışanları açısından etkileşimi ortaya koyarak alan yazına katkı sağlamak amaçlanmıştır. Aktör ăg kuramına göre doğal olarak oluşmuş bu kuşak yine kuramda belirtilen teknolojiorganizasyon-birey etkileşiminin unvan ve cinsiyet denklemlerine sinizm boyutlarında anlamlı olup olmadığı anket yöntemiyle test edilmiştir. Araştırma evreni, Türkiye'de faaliyetlerini yürüten katılım bankalarının $Y$ kuşağı çalışanlarıdır. Faktör analizi, t-testi ve korelasyon analizi ile elde edilen bulgular Y kuşağına mensup katılım bankalarında çalışan bireylerin kişilik sinizmiyle birlikte demografik özellikler olan gelir, unvan ve cinsiyet değişkenlerinin örgütsel sinizmin boyutlarında farklilıklar oluşturduğu bulgusuna ulaşılmıştır. Bu bulgular neticesinde katılım bankalarının Y kuşă̆ı çalışanla$r l$, literatürde algılandığının aksine sadece yaş değil, unvan ve cinsiyet boyutlarında da olsa sinizme maruz kaldığg gözükmektedir. Örgütsel sinizmin $Y$ kuşağı çalışanları üzerine yapılan bu araştırmanın; benzer çalışmaların yetersiz olması ve elde edilen bulgular bakımından önemli olduğu düşünülmektedir.
\end{abstract}

Anahtar Kelimeler: Örgütsel Sinizm, Y Kuşağı, Kültürel Fark Grupları 


\title{
Organizational Cynicism From Generation Y Perspective
}

\begin{abstract}
Organizational cynicism is expressed as the negative behavior and attitudes of the employees to their organizations. Generation Y is defined as individuals born between 1981 and 2000, although there is no clear consensus between the dates. Generation $Y$, which is the latest in the business world and more than other generations in terms of a number, shows its effects all over the world and forces many organizations to change their way of doing business. Although cynicism is stated to be distinguished, low level of satisfaction, criticism, interest in itself, and a negative point of view, its effect on generations has not been explicitly investigated. With this research, it is aimed to contribute to the literature by revealing the interaction of organizational cynicism for Generation Y employees. This generation, which was naturally formed according to the actor-network theory, was again tested by the questionnaire, whether the technology-organization-individual interaction specified within the theory is meaningful to cynic dimensions to title and gender equations. Research universe, Generation $Y$ employees are carrying out the activities of participation banks in Turkey. Survey results are analyzed by factor analysis, $t$-test, and correlation analysis. It has been found that individuals working in participation banks belonging to generation $Y$, together with personality cynicism, show differences along the dimensions of organizational cynicism, income, title, and gender. As a result of these findings, Generation $Y$ employees of participation banks seem to be exposed to cynicism, not only in age but also in title and gender, contrary to what is perceived in the literature. This research on organizational cynicism of Generation $Y$ employees is important in terms of inadequate studies and important findings.
\end{abstract}

Keywords: Organizational Cynicism, Generation Y, Cultural Difference Groups 


\section{Giriş}

Günümüzdeki işletmelerde farklı yaşlarda bireyler çalışmaktadır. Yeni nesillerin iş yaşamında yerlerini almasıyla oluşabilecek beklentilerin açıklarını gidermenin yanında muhtemel sorunların oluşmasını engellemek, bu nesillerin beklenti ve akıl yapılarını inceleyerek anlamayı çalışmaktan geçmektedir. Türkiye'de genç nüfusun fazla olması 1981-2000 yılları arasında doğmuş olan $Y$ kuşağı bireylerin iş hayatında önemli biçimde yer aldığını göstermektedir. Y kuşağı için temel ihtiyaçlarının karşılanmasının büyük ölçüde sağlandığı bir toplumda çalışmanın farklı bir amacı olmalıdir(Schulenburg, 2016). Kendinden önceki kuşaklardan özellik yönünden farklılaşan Y kuşağına yönelik farklı çalışmalar yapılmış olmasına karşın (Altuntaş, 2017; Arun ve Arslan, 2019) örgütsel sinizmin etkilerine yönelik yapılmış çalışmaları kısıtlıdır. Türkiye'deki nüfus verilerine bakıldığında yüzdesel olarak en fazla sayıda bulunan yaş grubu (Tablo 1) Y kuşağı olması nedeniyle araştırması yapılan konuların başında yer alması gerektiği düşünülmektedir. Fakat doğrudan yaş temelli nesillerin popüler kavramlarını ifade eden örgütsel araştırmalar sınırlıdır ve sayısız zorlukla karşı karşıyadır (Joshi vd., 2011). Bu konuda genel eksiklik çoğu araştırmanın milenyumlar gibi oluşturulan keyfi grupların sabit formlar olarak var olduğuna ve bir gruptaki bireylerin ortak değerleri paylaştıklarını ve organizasyonlarda da orak nitelikler sergilediğini kabul etme eğilimidir (Parry ve Urwin, 2011). Bu nedenle her kuşağın işletmedeki davranış biçimleri ve yaş dışındaki değişkenlerine ayrıca bakılması gerekmektedir. Tablo 1'de görüleceği üzere $Y$ kuşağ1 toplumun en büyük yüzdesini oluşturmaktadır. Diğer önemli bir husus bu grup iş hayatında hâlihazırda en fazla aktif olan kuşak olduğundan diğer kuşaklara göre örgütsel sinizmin etkilerini daha fazla hissetmekte veya yaşamaktadırlar.

Tablo 1. Kuşakların Genel Nüfus İçerisinde Dağılımı ve Oranları

\begin{tabular}{lllll}
\hline Kuşak & Toplam milyon & $\begin{array}{l}\text { Erkek } \\
\text { (yaklaşık) milyon }\end{array}$ & $\begin{array}{l}\text { Kadın } \\
\text { (yaklaşık) milyon }\end{array}$ & Oran \\
\hline Z Kuşağı & 22883288 & 11 & 11 & $28,32 \%$ \\
\hline Y Kuşağı & $\mathbf{2 4 3 3 4 4 8 4}$ & $\mathbf{1 2}$ & $\mathbf{1 1}$ & $\mathbf{3 0 , 1 1 \%}$ \\
\hline X Kuşağı & 20980588 & 10 & 10 & $25,96 \%$ \\
\hline Bebek Patlaması Kuşağı & 9352126 & 5 & 5 & $11,57 \%$ \\
\hline Sessiz Kuşak & 3260039 & 1 & 2 & $4,04 \%$ \\
\hline Toplam & 80810525 & 41 & 40 & $100 \%$ \\
\hline
\end{tabular}

Kaynak: Adrese Dayalı Nüfus Kayıt Sistemi (ADNKS) Sonuçları, 2017 
Özellikle teknoloji kullanımının yaygınlaşması ve teknolojinin daha karmaşık hale gelmesi iş dünyasını da en üst düzeyde etkilemektedir. Çeviri sosyolojisi olarak da bilinen Aktör A ğ Kuramı (ANT), 'sosyal ilişkilerin' maddi ve doğadan bağımsız olmadığı fikrini savunmaktadır (Wessells, 2007). Aktör ağ kuramı özellikle teori aktörlere ve onların eylemlerini, özelliklerini, niyetlerini, ahlaklarını sağlayan şeylere odaklanır (Latour, 1999). Yani kurama göre aktörlerin kendi çabalarını ve eylemlerini birbirleriyle koordine etme süreci önemlidir. Kuramın önemli vurgularından bir tanesi de sosyal aktörlerin davranışlarını doğrudan açıklamak yerine, aktörlerin ne yaptıklarını ve sosyal güçlerden nasıl etkilendiklerini hâlihazırda bildikleri yaklaşımı benimsemesidir (Miles, 2012). Y kuşağına sahip bireyler de yaş özelliklerinden dolayı temel olarak bu kuşağın getirdiği değişim ve bakış açılarına sahip olarak doğal şekilde yetişmişlerdir. Bununla birlikte ANT'ye göre işletmeler, sosyal teknik, bağlamsal, vb. şekilde doğal olarak oluşan az çok istikrarlı ittifaklarla bir araya getirilen heterojen aktörler şeklinde tanımlanabilir (Law, 1990). Bu durumda kuramda eksik kısım, yapay olarak oluşturulmuş kategorileri, yapıları ve benzerlerini, başka bir deyişle organizasyon içerisinde çalışma hayatına girilmesiyle yapay olarak oluşturulmuş sistemlerin etkisini aktörlerden davranışlardaki yansımasını öğrenmektir (Fenwick ve Edwards, 2010).

ANT doğal nesnelerin ve insan yapımı eserlerin ağın göreli dayanıklılığını veya zayıflığını açıklayan bazı 'gerçek' özelliklere sahip olduğu fikrine dayanır. Teknoloji de aktör-ağ kuramında bu ağ belirleyici olarak görülebilir. ANT, teknolojik özcülük yaklaşımmna da sahiptir. Başka bir ifadeyle ANT teknolojiye aktörleri etkileyen bir materyal gözüyle bakar. Diğer ifade şekliyle, teknoloji aktörlerin ağ oluşturmasında yapısal ajanlar olarak görev yapar. ANT'nin teknolojiye bakış açısında iş hayatındaki gelişmeler, büyük endüstri değişikliklerini IT teknolojileri veya elektronik ticaret sistemleri gibi teknik buluşlara bağlamaktadır (Mutch, 2002). Bunun nedeni ise teknolojinin aktör ve bağ arasında katalizör görevi görmesidir. Kimya biliminden de hatırlanacağı üzere katalizörler ağ yapısını olumlu yönde etkileyebilecekleri gibi olumsuz yönde de yavaşlatabilirler. İş hayatında bu duruma baktığımızda Y kuşağının kendi doğal olarak kabul ettikleri yaş ve o günkü koşulların içinde yaşamaktan kaynaklanan aktör oluşum süreci teknoloji, organizasyonel güvenlik ve hatta organizasyonun kendisine bağlamaktadır (Whittle ve Spicer, 2008). Y kuşağının kendisi de teknoloji ve hızlı değişen 
bir dönem içerisinde yer almışlar ve doğal olarak bu özelliklerini iş hayatına taşımışlardır. Buna karşın işletmenin teknoloji, yönetim yapısı ve hatta kendisinin, Y kuşağı aktörler tarafından ağ üzerindeki algısının farklı olması, bu kişilerin işletmelerde sinizm bakış açısıyla hareket etmesiyle sonuçlanabilinir.

En basit ifadeyle, örgütsel sinizm, çalışanların kurumlarına güvenmediklerinde ve örgütlerine karşı güvenilmez olduklarını hissettiklerinde meydana çıkar(Kim vd., 2019). Örgütsel sinizmin birçok tanımı hayal kırıklığı ve öfke gibi duygularla alakalıdır (Ajzen, 2001). Sinizm araştırmaları, bir organizasyon veya örgütün içindeki bireylerin eylemlerine odaklanmıştır (Pugh vd., 2003). Örgütsel sinizm, örgütler arası uygulama ve davranışlardaki farklılıkların yanı sıra bireysel farklılıklardan da kaynaklanmaktadır (Akar, 2019; Bommer vd., 2005; Johnson ve O'Leary-Kelly, 2003). Y kuşağı bireylere göre, otorite ve klişeler herkesin gerçeği görmesi için yok edilmelidir. Sinizm "otoritenin yıkılması" yoluyla örgütleri ve üyelerini etkileyebilir (Goldner vd., 1977). Böylece bu durumun, iş ile özel hayatın dengede tutmak isteyen, eğitim düzeylerinin yüksek olması sebebiyle işyerinden ziyade işin kendisini önemli bulan $Y$ kuşağına mensup bireyler için fazlaca öne çıkacağı düşünülmektedir. Bunun yanında "tanımlanan" ve "tanımlanmayan" örgütsel sinizmin birbirlerinden ayırt edilmesi çok zordur. Bunun sebebi örgütlerde meydana gelenlerin çoğunun başka yorumları söz konusu olmasıdır (Pfeffer, 1981). Sebep-sonuç ilişkisi oluşturması bakımından örgütsel sinizmle başka kuşakların yanında diğer örgütsel kavramların da araştırılmasının önemli olduğu düşünülmektedir.

Araştırmacılara göre, $X$ ve $Y$ kuşaklarının yaşama yönelik pragmatik görünümlerinin benzerlikler göstermesine karşın farklılıklar taşıdığ1 düşünülmektedir. Bu durumda insan genleri ve çevrenin etkisi olmak üzere iki faktör öne çıkmaktadır (Roth, 2017). Y kuşağı bireyleri, iyimser ve idealist olmalarının yanında geleneğe yatkın olmalarıyla beraber sinizmin belirtilerini daha az göstermektedirler. Bu açıdan bakıldığın da Y kuşağı bebek patlaması kuşağıyla daha fazla benzerlik göstermektedir (Reisenwitz ve Iyer, 2009). Genellikle Y kuşağı; esnek, olumlu, ekip ruhuna uygun ve birden fazla görevi yapabilmektedir (Durkin, 2008).

$\mathrm{Bu}$ araştırmadaki temel amaç $\mathrm{Y}$ kuşağına mensup bireylerin sahip oldukları özellikler yönünden örgütsel sinizmin boyutları arasında varsa ilişki ve ilişkinin yönünün araştırılmasıdır. Diğer bir ifadeyle $Y$ kuşak bireylerini 
başka kuşak bireylerinden ayıran özelliklerin örgütsel sinizm ile aralarındaki bağlantıların ortaya çıkarılmasıdır. Fakat daha önce yapılan çalışmalar sinizmi genel olarak incelemiş ya da çok fazla değişkenin birbirleriyle olan ilişkisini araştırmıştır. Oysaki her iki durumun neticesi de bir yapıya çok fazla değişken yüklemenin bilgi kaybına ve araştırma bulgularının yanlış yorumlanmasına yol açabileceğini göstermiştir. Bu nedenle çalışmada demografik değişkenleri temsilen cinsiyet ve örgüt etkisini temsilen unvan kavramları tercih edilmiştir. Bu araştırmanın bilimsel yazına katkısı üç şekilde olmaktadır. Birincisi aktör-ağ kuramı çerçevesinde belirtilen organizasyon yapısının doğal yollarla belirlenmiş $Y$ kuşağının sinizm davranışlarına etkisinin araştırılmasıdır. İkinci ise her ne kadar $Y$ kuşağı yaş ile belirlenmiş olsa bile cinsiyetin etkisinin sinizm boyutları üzerinde farklılık oluşturup oluşturmadığının belirlenmesidir. Üçüncü olarak ise sinizmin bir bütünden ziyade her bir boyutunun ayrı olarak ele alınmasıdır. Bu amaçla yapılan ankete dayalı veri toplama yöntemi ile katılım bankaları çalışanlarının katılımı ile görgül bir araştırma yapılmıştır.

\section{Bilimsel Yazın}

İşyerindeki nesiller, kapitalizm tarihinin çeşitli noktalarında meydana gelen ve işin sosyal yapısında dönüşümlere yol açan önemli olaylara atıfla tanımlanır. Bireysel ve sosyal yaşamın bir gerçeği ve aynı zamanda deneyim olarak, çalışma kökten değişmiştir. Sonuç olarak, nesillerin iş ile ilişkisi veya yönelimi de önemli ölçüde değişmiştir (Hurst ve Good, 2009; C. Schmidt vd., 2011; K. Schmidt vd., 2012). İşi merkeze alan tartışmalar, işteki yaş grupları arasındaki tutum farklılıklarının gözlenmesi, özel olarak kadın işgörenler ile ilgili oluşturulan tezler, hepsi bu sosyal değişimler karşısındaki belli bir etkiye işaret eder. Burada nesiller/kuşaklar boyutu çok önemlidir (Krahn ve Galambos, 2014). Farklı bağlamda sosyalleştikleri ve spesifik deneyimlerinde farklılıklar olduğu göz önüne alındığında, işe karşı farklı kuşakların farklı yönelimlerinin bulunması beklenebilir (Nazarian vd., 2017). Y kuşağının, performansa güçlü bir şekilde odaklanmasının bir nedeni de artan rekabetçi bir toplumdur (Charters vd., 2011). Y Kuşağı'ndan önce rekabetçi bir toplum bulunmakla birlikte, küreselleşme ve özellikle de Avrupa Birliği nedeniyle, daha yoğun hale gelmiştir. Y kuşağı yüksek eğitim seviyesinde olduğundan farklı perspektiflerden görülmesi gerekir: Birincisi, mes- 
leki eğitim ve çalışmalara önceki nesillere kıyasla harcanan daha uzun zaman önemlidir. İkincisi, artan refah, birçok insanın mümkün olan en kısa sürede kendi paralarını kazanmak için bir işe girmesi için baskı yapmıştır (Moscardo ve Benckendorff, 2010).

Y kuşağı özellikle belirgin bir sosyal davranışa sahiptir (C. Schmidt vd., 2011). Bireyler bir kültür tarafından belirlenen normlara uymak istiyorsa ve eğer bunu yapacak kaynaklara sahiplerse, standart bir kariyer, yani hâkim, baskın yaşam iş kariyerlerini talep ederler. Buna karşın bir normatif gündeme uymayan işgörenler normlardan uzaklaşarak bireyselleştirilmiş bir yaşam yolunu takip edebilirler. Bu nedenle, bu tür bireyler rollerini, konumlarını ve kimliklerini müzakere ederler, hatta bazen bu bireyler yaşamlarının farklı aşamalarının gelişimi için yeterli olanaklar sağlamayan işletmeler veya kurumlar için daha güvenilmezdir (Méda ve Vendramin, 2017). Kuşakların işe karşı tutumlarımdan, geniş ölçüde, bireylerin işlerini tanımlarken harekete geçirdikleri temsiller değil, aynı zamanda orada bulunmayı umdukları yeri ve onları motive eden değerleri de içerdiği anlaşılmalıdır(Vendramin, 2010). Kısaca Y kuşağı bireyleri, işe karşı farklı tutumlar geliştirebilirler ve bu tutumlar pozitif ya da sinizm gibi negatif olabilir. Bununla birlikte bahsedilen özelliklerin Y Kuşağı'ndan bir kişi için geçerli olma şansı yüksektir, ancak bu, çalışanların bireysel olarak değerlendirmesi ihtiyacını göz ardı edemez.

Çalışanlar arasında sinizmi incelemenin önemli olmasının nedenleri yaygın yönetim güvensizliği, diğer çalışanları küçümseme eğilimi ve dedikodu ve dedikodu ile değişime karşı direnişlerdir. Sinizm kısaca, organizasyonların dünya ve yerel ekonomideki rekabet gücünün zayıf olmasına yol açmaktadır (Whitener vd., 2012). Çalışanların işletmenin kendilerini tamamlayıcılıktan ve ortak çalışma kültüründen yoksun olduğuna dair inanc1, özellikle $\mathrm{Y}$ kuşaklarında olumsuz duygular geliştirmelerine buna bağlı olarak olumsuz tutum ve davranışlara daha yatkın olmalarına neden olabilir (Akar, 2019; Naseer vd., 2020; Naus, 2007).Örgütsel sinizmle alakalı farklı birçok tanım yapılmış olmasına rağmen (Kalağan ve Aksu, 2010) temel olarak kullanılan Dean vd. (1998)'nin, bireyin çalıştığ işletmeye karşı olumsuz tutum geliştirmesi şeklinde yapmış olduğu tanımdır. Sinizmin kavramsallaştırılması, ilgili kavramlar, odaklar, tanımlar, epistemik ilişkiler, farklı sinizm formlarıyla karşılaştırmalar, iç güvenilirlik, belirleyicilerin göreceli önemi (örneğin, kişilik özelliklerinin etkisine karşı durumsal özellikle- 
rin etkisi) ve yapıyı etkileme araçlarının literatürde varsayılan süreklilik düzeyleridir(Dean vd., 1998). Sinizmi anlamanın bir yolu, insanların çevrelerini değerlendirmek ve psikolojik stresle baş etmek için kullandıkları bilişsel süreçlerle ilgilenen bilişsel değerlendirme teorisidir (Biggs vd., 2017). Teoriye göre organizasyonlarda çalışanlar stresle nasıl başa çlkmaya çalışırken hem kendi (bireysel) durumunu nasıl değerlendirdiği hem de çalışma ortamını içeren bağlamsal faktörlerden nasıl etkilenildiğini açıklamaya çalışrr(Shelton, 1993).

Çalışanların gösterdiği sinizm ile tutumlar bilişsel (inanç) boyutu, duyuşsal (duygu) boyutu ve davranışsal (davranış) olarak üç boyutta ele alınmıştır (Dean vd., 1998; Pelit ve Pelit, 2014). Örgütsel sinizmin bilişsel (inanç) boyutu; işletmelerin karşılıklı bütünleyici olmadıkları ve çalışanların işletmeyi dürüst olarak algılamadıkları inancını ifade etmektedir. Örgütsel sinizm konusunda yüksek olan bireyler artan sinirlilik, aşağılanma ve örgütlerine karşı kızgınlık gibi olumsuz duygular geliştirir, bu da onları kaynaklarda yetersiz k1lar (Abraham, 2000; Naseer vd., 2020). Organizasyondaki bireyler tarafinda bu tip genelde olumsuz olarak ifade edilen duygular duyuşsal boyutu tanımlamaktadır. Davranışsal boyut, ise kişilerin inançlarının, düşüncesinin davranışına etki etmesi durumudur (Arslan, 2019; Pelit ve Pelit, 2014).

Bireysel düzeyde, organizasyon üyelerinin çaba ve etki (sonuç) arasında algılanan uyumsuzlukların sinizminin önemli bir öncüsü olduğu kabul edildiğine dair çalışmalar mevcuttur(Munir vd., 2018). Buna karşın çalışanlar soru sormaya ve duyguların ifade etmekte isteksiz olan başkalarının yerine konuşmaya başladıklarında organizasyon tarafından sinizme sahip bireyler olarak etiketlenebilirler. Bunların sebebi genelde mesleklerde yaygin olarak görülen bir rol çatışması veya rol belirsizliği algısı olarak kabul edilir(Andersson, 1996). Bununla birlikte dağıtıcı, prosedürel ve etkileşimsel adalet ayrı ayrı incelendiğinde de örgütsel sinizmi etkiledikleri görülür (Arslan, 2019). Ayrıca, psikolojik sözleşme ihlali ve yanlış algılanan örgütsel politikaların sinizmi arttırdığı tespit edilmiştir (Chiaburu vd., 2011).

Bireysel açıdan bakıldığında, kişilikten kaynaklanan sinizm, organizasyondaki diğer bireylere güvenilmemesinin genel bir inancı olarak kavramsallaştırmıştır (Costa vd., 1986). Yüksek kişilik sinizmi gösteren çalışanlar, diğer işgörenlerin bencil, aldatmaya yatkın olduğuna inanırlar ve mümkün olduğunda diğerlerini kendi çıkarları doğrultusunda kullanabilme eğili- 
mindedir. Örgütsel sinizmi oluşturan diğer bireysel faktörler ise cinsiyet, yaş, eğitim durumu, medeni hal, gelir, hizmet süresi, bulunduğu konum olarak belirtilebilir (Arslan, 2019; Tokgöz ve Yılmaz, 2008). Özellikle yaş boyutunun çalışanların iş hayatına yönelik birçok etmeni etkilediği farklı çalışmalar ile gösterilmiştir (Horváthová vd., 2019; J. James vd., 2011). Bu bakımdan yaş farklılıklarının sinizm üzerindeki etkilerinin özellikle dikkate alınması gerekmektedir. Örgütsel sinizmin bilişsel, duyuşsal ve davranışsal boyutlarında bireyler farklı tepkiler gösterebilirler. Bilişsel boyutta, çalışanlar örgüt içinde adalet, dürüstlük ve samimiyetin eksik olduğuna ve kişisel çıkarların kararlarda ön saf olduğuna inanmaktadır. Örgütsel sinizmin duyuşsal boyutundaki çalışanlar öfkeli, nefret dolu ve örgüye karşı utanabilir. Duygusal tepki bireylerinde dokuz temel duygu; sevinç, korku, utanç, öfke, heyecan, sıkıntı, tiksinme, şaşkınlık ve hor görmedir (Cutler, 2000).

"Sinizm" anlamı ile ilgili iki versiyon en önemlisidir. Birincisi, eski Yunanistan'da bir yer adı olarak Atina dışında, 'değersiz' olduğu düşünülen insanlar için ayrılan bir spor salonu olan "Cynosarges"ten gelmektedir(Matson, 2000). Aynı zamanda, Cynic bir partiden dışlanan olarak "dışarıdakiler" şeklinde statüde temsil etmektedir. Sinizm diğer anlamı ise etimolojik yakınlığına dayanan köpekler veya kinos (kynos)'tan gelmektedir(Schutijser, 2017). Bunun sebebi köpeklerin hem arkadaşlarına sadık hem de düşmanlarına şiddetli tepki veren bir hayvan olarak bilinmesidir. $\mathrm{Bu}$ özellikler sinizmin eski zamanda kullanılan ve Stoacı (Logos) (acılara katlanan) insanlarl; Epicurean (Eros) (keyfine düşkün) akranlarından anlamına dayanmaktadır. Bu tarihsel ve etimolojik kökenleri dikkate aldığımızda da sinizmin aslında farklılıkları ve ayrılıkları tanımladığı görülmektedir. Bu tanımlar farklı grupların sinizm üzerindeki etkisinin olabileceğini ortaya koymaktadır. Günümüz iş dünyasında en belirgin farklılıklardan bir tanesi de çalışmamızda tanımlandığı gibi "kuşaklardır".

Bu çalışmada sinizme bakış kuşaklar arası bir perspektif olarak benimsenmiştir. Çünkü farklı kuşaklara bakış açısı, işgücü piyasasının farklı deneyimlerinin değişen sosyal bağlamla ilişkili olmasına izin vermektedir. Aynı zamanda Y kuşağındaki bireylerin aidiyeti yaş ile eşanlamlı değildir (her şeyden önce ayırt edici özelliklerle işaretlenmiş biyolojik bir olgudur, aynı zamanda yaşam seyrindeki bir pozisyonu da tanımlar) ama Y kuşağında olmak paylaşılan bir deneyim meselesidir(Méda ve Vendramin, 2017). Başka bir anlatımla ifade etmek gerekirse bir nesil grubunun içinde 
geliştiği sosyal bağlam o grubun psikolojik değerlerine, iş hayatına olan bakış açısına, iş ahlakına, çalışma amaçlarına ve isteklerine yönelik tutumlarina etki etmektedir (Wey Smola ve Sutton, 2002). Bu sebepten dolayı sinizmin neden ve sonuçları her nesil için farklı olabilir ve akademik olarak incelenmelidir.

Mannheim vd. (1972), kuşakları aynı zaman ve sosyo-kültürel bağlamda doğmuş, benzer deneyimleri olan ve sonuçta birleştirici ortaklıklar geliştiren bir grup birey olarak tanımlar. Bu nedenle, bu teorik bakış açısından, nesiller sadece belirli süreli yıllık doğum zaman aralıkları değildir. Ayrıca, nispeten küçük tutumsal veya davranışsal farklılıklar temelinde bir dizi bitişik belirli yıllarda doğmuş gruba kuşak adı atanmamalıdır(Krahn ve Galambos, 2014). Buna karşılık, örnek olarak, belirli zorlukları ve deneyimleri yaşamış bireyler benzersiz bir nesil olarak kabul edilebilir. Bu farklı yaşam deneyimleri, kuşakları birbirinden ayırır. Buna karşın bu deneyimlerin olduğu zamanı yaşamasının temeli doğum yılı veya yaştır. Dolayısıyla bir işgören organizasyonlara karşı duygularını, işten istediklerini ve yaşa bağlı olarak ta geliştirir (Kupperschmidt, 2000). Yani, Y kuşağının ve işletmelerin karşılıklı ilişkiler kurması (tek taraflı ilişkilerden farklı olarak) gerekir(Morton, 2002).

Araştırmacılar çoğu zaman nesillerin farklılaşması için üç nesnel kıstas sunar: ailede sosyal rol (V.i, 2011), yaşamın tarihsel dönemi (Edmunds ve Turner, 2006) ve doğum yılı (Altuntaş, 2017; V. I. Pishchik, 2018). Literatürde birbirinden yaş kriterine dayalı olarak ayrılan beş farklı kuşağın mensupları günümüzde iş hayatındadırlar. Y Kuşağı (1981 ile 2000 arası doğumlular) ve $Z$ Kuşağ 12000 yılı ve sonrasında dünyaya gelenler) olarak çalışmada ele alınmıştır. Örgütsel sinizm, örgütsel deneyimlerinden kaynaklanan (Wanous vd., 2000) tepkiler ve deneyimlerden oluştuğundan her kuşağın ayrı tecrübeye sahip olacağı varsayılabilir. Genellikle bilgi çağının zamanında doğan ve yaşayan $Z$ kuşağı yenilikçi zihniyet ile karakterize edilirken, $Y$ kuşağı geçiş kuşağı olarak hem yenilikçi hem de geleneksel zihniyet ile karakterize edilebilir (V. I. Pishchik, 2018). Daha önce yapılan çalışmalarda toplumsal ve bireysellik endeksleri arasındaki fark kuşaklar arasında anlamlı bulunmuştur. Y kuşağının temsilcileri tarafından temel olarak sorunlar kültürel bağlamı da içerir.

Kuşaklar tipolojisinin sadece demografik (özellikle doğum yılı) özellikleri değil; kültürel, sosyal ve tarihsel özgül nitelikleri vardır. Kuşakların yaşam yılları, ortalama olarak, yaklaşık 15 yıldır(V. I. Pishchik, 2018). Y kuşağı 
üyeleri bireysel, iyi eğitimli, teknolojik açıdan anlayışlı, sofistike, olgun ve yapilandırılmış olarak tanımlanmıştır (B. Valentine ve L. Powers, 2013). Psikolojik özelliklere dayanan kuşak ayrımları insanların nerede yaşadığını, zamanlarını nasıl harcadıklarını, kendilerini ve dünyalarını nasıl gördüklerini ve çevrelerindeki önemli şeyleri ölçer (Plummer, 1974). Yani Y kuşağ1 sadece doğum yılına göre değil iş hayatında çevre, algı, zaman yönetimi özellikleriyle de diğer kuşaklardan farklılık göstermektedirler. Bu kuşak mobil aygitlar, internet ve kendi teknik yaklaşımları nedeniyle iş hayatındaki en bağlantılı nesildir (Wey Smola ve Sutton, 2002). Önceki nesillerden farklı olarak, iş yaşam dengesinde daha çok yaşam yönüne ağırlık vererek aile, arkadaşlar ve kişisel uğraşları ihmal etmek istemezler. Bunun sonucunda, Y kuşağı nesilleri işlerine değil ama işyerlerine önceki nesillere göre daha az sadıktır. Y kuşağı çalışanı, bir işverenin insan ilişkilerine yatırım yapmadığını algilarsa, daha az bağlılık, güven ve sadakat duygusu hissedebilir ve bu kolayca sadece finansal ödül için çalışacaklarını hissetmesine yol açar(Kultalahti ve Viitala, 2015; Sonnenberg vd., 2011). Bu nedenle, Y kuşağ çalışanları, iş ve yaşam hedeflerini dengeleyebildikleri sürece işyerine sadıktırlar (Reisenwitz ve Iyer, 2009).

Başarılı işletmeler başarılı çalışanları hızlıca bulup, şirketlerine kazandırıp ve uzun yıllar elinde tutabilme önceliğindedirler. Özellikle katma değeri yüksek işlerde yeterli kalifiye personel olmadığından artık çalışanı işveren seçemez (Schulenburg, 2016). Y kuşağının iş hayatındaki beklentileriyle ilgili olarak tutumlar ve davranışlarla ilgili diğer kuşaklardan ayıran özelliklerini ortaya koyan çeşitli çalışmalar mevcuttur. Bu araştırmalar, işin içeriğinin önemini (De Hauw ve De Vos, 2010), eğitim ve gelişimin önemini (Sturges vd., 2002), sosyal bağlantılar ve işbirliği (Macky vd., 2008), iş-yaşam dengesi (Cennamo ve Gardner, 2011), kendini gerçekleştirme, yapısal faydalar ve besleyici ve destekleyici bir çalışma ortamıdır (Solnet ve Hood, 2008). Bu bakımdan kendileri için anlam ifade eden, pratikliklerini gösterebileceği ve enerjilerine uygun işlerin verilmesi bu kuşak için önemlidir. Yani sadece yaş değil işin ve iş hayatının sembolik anlamı (Blumer, 2009), Y kuşağı için önemli oluğundan diğer kuşaklardan farklı olarak örgütsel sinizmden anladıklarının da farklı olması beklenmektedir.

Organizasyonlar içerisinde grup benzerlikleri veya farklılıklarından kaynaklanan kültürel gruplar bulunmaktadır(Humphrey vd., 2006). Hassi vd. (2015)göre farklıkların temellerinde yaş, cinsiyet, deneyim bulunmakta- 
dır. İşletmelerde etkin yönetimler bu farklı grupların hem bireysel (iş tatmini vb.) hem de organizasyonel çıktılarını (performans vb.) yönetmek durumundadır (Cox, 1994). Bunun kuşaklara yansıması olarak, Y kuşağını diğer kuşaklardan ayıran birçok özellik bulunmasına rağmen en önemlileri yaş ve bunun işyerine yansıması olan unvandır. Hulin ve Judge (2003) biyolojik karakteristikler ve yaşam-deneyimi değişkenlerini sinizmi de kapsayan temel benlik değerlendirmesine (core evaluations of others) bağlamıştır. Y'lerin bir başka özelliği de yaptıkları her işin verimli ve farklı olmasını istemeleridir(Berkup, 2014). Bu bakımdan hem unvan hem de yaş Y'lerin sinizme bakış açısında farklılık oluşturmaktadır. Niederhoffer (1967) tarafından yapılan çalışmaya göre sinizm çalışanlarda ilk yedi ila on yıl hizmet sırasında artmakta ve daha sonraki yıllarda azalmasına rağmen ilk işe girenlerde bulunan düşük seviyelere geri dönmemektedir (Bordua, 1968). Fakat Hicman vd. (2004) tarafından yapılan araştırmada cinsiyetin örgütsel sinizm üzerinde etkisi bulunmamıştır. İlginç olarak aynı çalışmaya göre kullanılan sinizm ölçeğine bağlı olarak unvanın etkisi değişiklik etkisi oluşturduğunu varsayabiliriz (Schulenburg, 2016). Sinizm literatüründeki araştırmalar sinizmi etkileyen faktörler ile çıktılar arasında hala daha fazla araştırma yapılması gerektiğini ortaya koymaktadır(Naseer vd., 2020; Scott ve Zweig, 2016). Bunula birlikte bu faktörlerin hepsinin bu çalışmada yer alması mümkün değildir. Naseer vd. (2020) tarafından yapılan çalışmada yaş, cinsiyet ve diğer demografik değerlerin önemi ortaya konmuştur. Ancak Canbek ve Kanbur (2020) tarafından yapılan araştırmada elde edilen sonuçlar yaş değişkeninin örgütsel sinizme etkisinin olmadığını ortaya koymaktadır. Sinizmin olumsuz ve olumlu etkilerinin zeminine karşı, araştırmacılar işletmelerin karmaşıklığını ve farklı birimleri içindeki sinizmin belirli örneklerini anlamanın önemli olduğunu belirtmişlerdir (Regoli vd., 1990; Spencer vd., 2019). Bu açıdan bakıldığında işletme içerisinde tek değil özellikle jenerasyonlar arasındaki farklılıklara dayanan seviyelerde sinizm boyutlarının bulunması gerekmektedir. Bu nedenle demografik özelliklerin etkilerinin çeşitli araştırmalara istinaden incelenmesi önemli bir konudur.

Farklılıklara dayanan sinizm yanında organizasyondaki bağlama dayalı sinizm de bulunmaktadır (Zhang vd., 2019). Bu yaklaşıma bağlı olarak örgütsel sinizm organizasyondaki süreçlerden etkilenmektedir. Yani organizasyon bağlamından ve dolayısıyla bu bağlamla alakalı yönetim süreçleri, organizasyon yapısı gibi çevre ve dinamiklerden etkilenir (Dean vd., 1998; 
Şen, 2019). Bazı araştırmacılar sinizmi iki unsura göre nitelendirmiştir. Birincisi yukarıda da açıklanan ve sinizm gösteren bireylerin özelliklere dayanan yaklaşımdır (Cook ve Medley, 1954). Bu yaklaşımın temeli bireylerin bazı özelliklerinin sinizm üzerinde etkili olduğudur. Bununla birlikte özellikler yaklaşımından farklı olarak belirli organizasyonel olaylar ve nesnelere karşı duyulan sinizm de bulunmaktadır(Fauzan, 2019; Şen, 2018). Sinizme yönelik bu yaklaşımlar, genel bir kişilik özelliğinden ziyade, nesnelerin kendileri hakkında varsayımlar, sinizmin kişide gelişmesine etki eder. Sinizm, organizasyon veya toplumun tümü gibi soyut kavramlara yönelebilse bile toplumda karşılaşılan hayal kırıklığı ve hayal kırıklığından kaynaklanan gerçekçi olmayan yüksek beklentiler ve yenilmiş hissetme duyguları sinizmin temelleri olarak görülmektedir(Kanter ve Mirvis, 1989). Toplum düzeyinden işletmeye doğru uyarladığımızda algılanan organizasyonel destek sinizmin üzerinde etkili olduğu bulunmuştur(Lynch vd., 1999). Fakat organizasyondan beklenen destek genel ve daha belirsiz bir kavram olduğundan bu çalışmada organizasyon boyutunu temsilen unvan kullanılmıştır. Yapılan bir çalışmada da yönetsel unsurların sinizm üzerindeki etkileri ortaya konarak özellikle örgütsel bağlllıkla birlikte unvan hususu araştırılmıştır (Scott ve Zweig, 2020).

Sinizm yukarıda açıklanan temellere dayanarak sadece hayal kırıklığı, umutsuzluk ve yanılgı değil; bir kişiye, gruba, ideolojiye, sosyal gruba veya kuruma karşı duyulan güvensizliğe de dayalı özel bir tutum olarak tanımlanabilir (Andersson ve Bateman, 1997). Kuşakları belirlemede temel anlamda iki yaklaşım vardır. Birincisi yaş temelli yaklaşım kuşakların doğum yıllarını dikkate alır. İkinci yaklaşım ise yaşam evresi yaklaşımıdır. Bu yaklaşıma göre sadece yaş değil kuşakların içinde bulunduğu yaşam evresinin önemi bulunmaktadır. Bir kuşağa ait olma duyusunun sadece sosyal veya yaşa bağlık olarak değil, aynı zamanda yaşam seyrinin ve tarihsel deneyimlerin bir fonksiyonunu olarak da oluştuğunu belirtir(Mayer ve Tuma, 1990). Mannheim (1970), değerlerin tecrübe yoluyla oluştuğu ve dolayısıyla paylaşlan deneyimin paylaşılan kimliğin oluşumuna yol açabileceğini öne sürerek deneyimlerin etkisinin, yaş grubu (demografik kategori) ile nesil (sosyal kategori) arasındaki farkı yaratan etken olduğunu söylemiştir (McCourt, 2012; Pilcher, 1994). Yani literatürde hem kurum hem de sosyal grup kavramlarını bir araya getirecek kavram kuşaklar olarak ele alındığında ve kuşaklar arasındaki farklar aktör ağ kuramına göre de açıklandığında sadece 
doğum yılı değil işletme bağlamında da açılanabilir. Bu anlamda bir nesil, ortak bir biçimlendirici deneyimden etkilenen temel inançlar etrafında birleşebilir (Wohl, 1981). Çünkü işletme bağlamı aynı zamanda grupların niyetleri, eylemleri ve ahlakını da etkiler (Joshi vd., 2011). Bu etkileşim, üyeleri tarafından tanımlanan uyumlu gruplarla değil, genellikle "dışarıdan bakanların algilarıyla" tanımlanan kuramsal kategorilerle ve sözde farklılıkların zıtlığıyla uğraştığımız gerçeğini yansıtmaktadır (Williams, 2020). Bu sebeplerle çalışmamızda jenerasyonların farkındalığını temel olarak tanımlayan yaş ve bağlamsal anlamda etkili olabilecek organizasyon hiyerarşik yapısını temsil eden unvan ve cinsiyetin etkileri araştırılmıştır. Medeni durum gibi değişkenler demografik değişkenlere dâhil olsalar bile kuşakların temel farklarını temsil edebilecek algılanan (Mannheim, 1970) değişkenler olarak bilim yazında karşımıza çıkmadığından araştırma dâhil edilmemiştir. Kısaca, organizasyonel bağlamda hem $Y$ kuşağı hem de organizasyon bağlamını temsil eden değişkenler cinsiyet ve unvan olarak belirlenmiştir. Çünkü yaş çok belirgin bir farktır ve organizasyonel bağlam ise çok muğlâk bir tanımdir.

Buna göre oluşturulan hipotezler aşağıdaki gibidir:

- Hipotez 1.1: Örgütsel unvan, sinizm faktörlerinden bilişsel boyutu pozitif yönde etkilemektedir.

- Hipotez 1.2: Örgütsel unvan, sinizm faktörlerinden duyuşsal boyutu pozitif yönde etkilemektedir.

- Hipotez 1.3: Örgütsel unvan, sinizm faktörlerinden davranışsal boyutu pozitif yönde etkilemektedir.

- Hipotez 2.1: Cinsiyet, sinizm faktörlerinden bilişsel boyuta göre farklılık göstermektedir.

- Hipotez 2.2: Cinsiyet, sinizm faktörlerinden duyuşsal boyuta göre farkll1ık göstermektedir.

- Hipotez 2.3: Cinsiyet, sinizm faktörlerinden davranışsal boyuta göre farklılık göstermektedir.

\section{Araştırma}

Bu araştırmayla Türkiye'deki katılım bankalarının Y kuşağına mensup çalışanlarının deneyimlemiş oldukları örgütsel sinizm düzeylerinin araştırılmaS1 amaçlanmıştır. 


\section{Araştırmanın Metodolojisi}

Örgütsel sinizmin ölçülmesi için Brandes (1998) tarafından geliştirilen ve sonrasında Türkçeye çevrilen (Erdost vd., 2017) 14 sorudan oluşan ölçekten faydalanılmıştır.

Araştırmaya yönelik sorular istatistiksel olarak analiz edilerek güvenilirlik, faktör analizi, korelasyon ve $t$ testleri ile sonuçlar yorumlanmıştır.

\section{Araştırmanın Örneklemi ve Evreni}

Araştırmanın katılım bankalarındaki çalışanlar üzerinde yapılmasındaki sebepler:

1. Araştırmacılardan birisinin katılım banklarında çalışıyor olmasından dolayı örnekleme ulaşma (izin vs.) daha kolay olması

2. Türkiye'de katılım bankalarının, bankacılık sektöründe her geçen gün daha fazla paya sahip olması

3. Katılım bankalarındaki çalışma ortamının diğer banka ve işyerlerine göre farklı olması (Baykal, 2019).

4. Bankaların iş ve beceriler arasındaki uyumun önemli olduğu ve çalışanların çıkarlarının kendine özgü fırsatlar sunduğu yerler olmasıdır (Morf vd., 2019).

Türkiye'de faaliyet gösteren altı katılım bankasının yurtiçi şubelerinde toplam 16.173 (TKBB | Veri Seti, 2020) personel görev yapmaktadır. Bu araştırma, Albaraka Türk, Kuveyt Türk, Türkiye Finans, Vakıf ve Ziraat Katılım Bankaları Anonim Şirketlerinin tüm Türkiye'deki ankete katılan Y kuşağı çalışanlarına uygulanmıştır. Yaş grubu olarak Türkiye genel nüfus sonuçlarına göre oranladığımızda yaklaşık $5391 \mathrm{Y}$ kuşağında personelin görev yaptığ1 değerlendirilmektedir. Israel (2013) göre örneklem büyüklüğü $\pm 5 \%$ kesinlikle ve $\% 95$ güven aralığında ve $\mathrm{P}=.5$. seviyesinde yaklaşık 5000 için 370 ve \%7 kesinlikle ise 196 kişi olarak belirtilmiştir. Ölçülen özelliklerde değişkenlik derecesi, özelliklerin popülâsyondaki dağılımına karşılık gelir. Popülâsyon ne kadar heterojen olursa, belirli bir hassasiyet seviyesi elde etmek için gereken örnek büyüklüğü o kadar büyük olur. Örneklemimizi Y kuşağ 1 ve katılım bankalarında çalışanlar oluşturduğundan popülasyon genel olarak homojen bir yapiya sahiptir. Bu nedenle toplanan ve analize sokulan anketlerin sayı bakımından yeterli olduğu sonucuna varılmıştır. Bu kapsamda basit rastgele yöntemiyle yaklaşık 500 kişiye anket dağıtılmış ve $Y$ 
kuşağında olan 215 kişiden dönüş alınmış, hatalı anketler çıkarıldıktan sonra 202 anket analize dâhil edilmiştir.

\section{Araştırmanın Sonuçları}

Araştırmaya Türkiye'de faaliyetlerini yürüten katılım bankalarında çalışan Y kuşağı bireylerden basit rastgele seçilen 202 kişi katılmıştır. Anketi cevaplayan katılımcıların \% 28,7'si Kadın (58 kişi), \% 71,3'ü (144 kişi) Erkek'tir. Katılımcıların \% 41,6'sı evli (84 kişi), \% 58,4'ü bekârdır (118 kişi). Anketi cevaplayan katılımcıların unvanları \% 52,5 i yetkili (106 kişi), \% 6,9'u uzman yardımcısı (14 kişi), \% 20,8'i uzman (42 kişi), \% 17,8'i yönetmen (36 kişi), \% 2'si müdür (4 kişi) şeklindedir.

Yapılan faktör analizi sonucunda (Tablo 2) örgütsel sinizm ölçeği literatüre uygun şekilde üç boyut altında toplanmıştır. Bu faktörler ölçeğin yüzde 72 'si gibi yüksek bir oranda açıklamaktadır.

Tablo 2. Örgütsel Sinizm Ölçeği Açımlayıcı Faktör Analizi Sonuçları ÖRGÜTSEL SİNIZMM ÖLÇEĞí FAKTÖR ANALİi̇

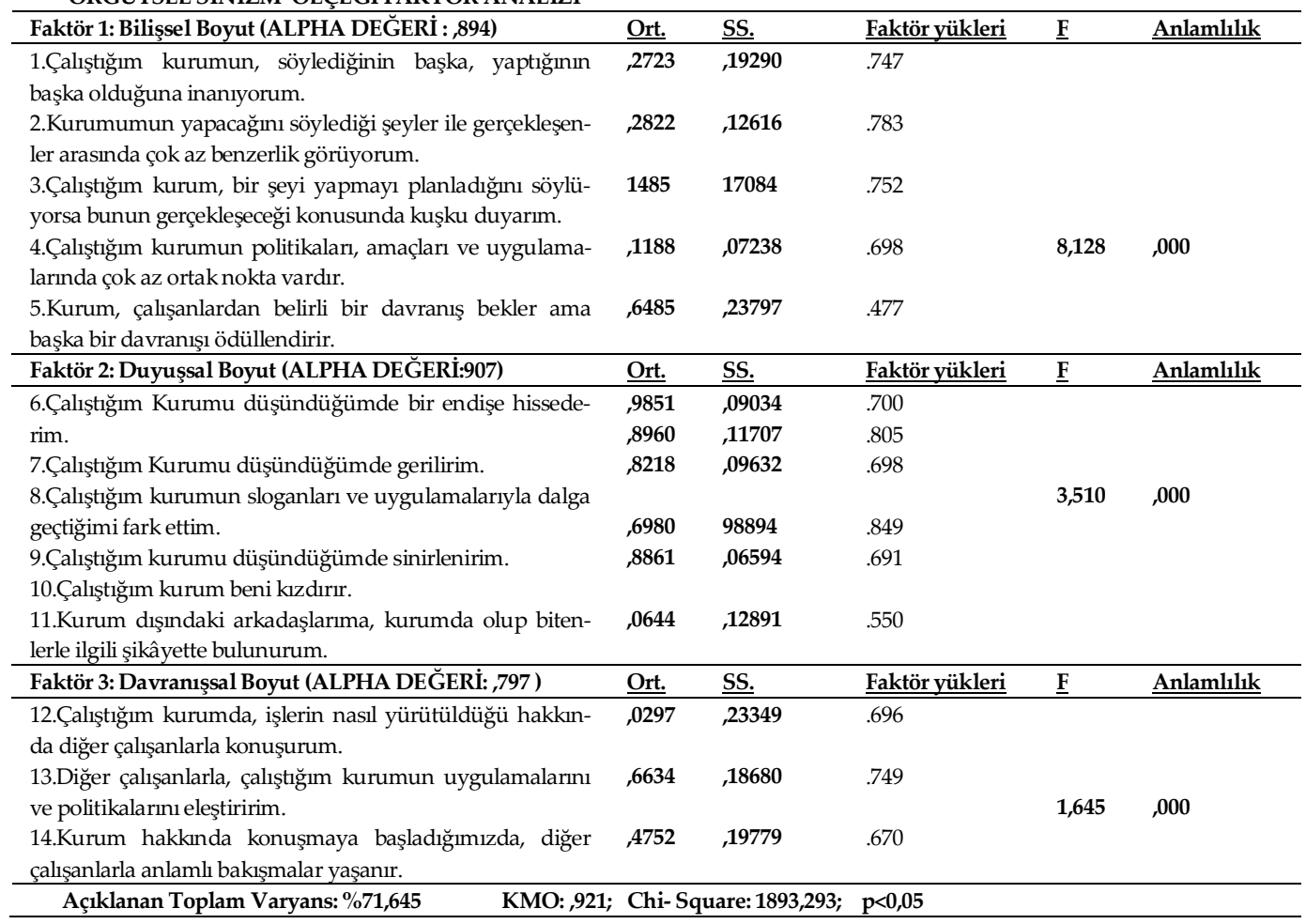


Oluşan faktörlerin güvenilirlik analizi Cronbach's Alfa katsayıları hesaplanarak kontrol edilmiştir. Bu hesaplama sonucu, sinizm ölçeğinin güvenilirlik katsayıları Tablo 3'te gösterilmiştir.

Tablo 3. Örgütsel Sinizm Ölçeği Güvenilirlik Analizi

\begin{tabular}{llll}
\hline & Cronbach's Alpha & $\begin{array}{l}\text { Cronbach's Alpha Based on } \\
\text { Standardized Items }\end{array}$ & $\begin{array}{l}\mathbf{N} \\
\text { (Soru Sayısı) }\end{array}$ \\
\hline Tüm Sorular İcin &, 927 &, 929 & 14 \\
\hline Bilişsel Boyut &, 891 &, 894 & 5 \\
\hline Duyuşsal Boyut &, 906 &, 907 & 6 \\
\hline Davranışsal Boyut &, 796 &, 797 & 3 \\
\hline
\end{tabular}

Faktör güvenilirliğinin $0,80 \leq \alpha<1,00$ arasında olması, ölçeğin yüksek seviyede güvenilir olduğunu göstermektedir (Tablo 3). Bütün sorular için olan güvenilirlik ölçeğinin alt boyutları açısından ayrı ayrı incelendiğinde yüksek derecede güvenilir olduğunu göstermektedir.

Örgütsel sinizm faktörlerinin araştırmaya katılan çalışanların unvanlarına göre farklılık gösterip göstermediklerini sınamak amaciyla yapılan korelasyon analizine göre şu sonuçlar elde edilmiştir:

Tablo 4. Unvan ile Örgütsel Sinizm Ölçeği Faktörleri Arasındaki Korelasyon

\begin{tabular}{lll}
\hline \multicolumn{2}{l}{ Korelasyonlar (Spearman's rho Correlation) N=202 } & Unvan \\
\cline { 2 - 3 } Bilişsel Boyut & Correlation & $\mathbf{1 7 9}$ \\
\cline { 2 - 3 } & Sig. (2-tailed) &, 011 \\
\hline \multirow{2}{*}{ Duyuşsal Boyut } & Correlation & $\mathbf{1 8 4}$ \\
\cline { 2 - 3 } & Sig. (2-tailed) &, 009 \\
\hline \multirow{2}{*}{ Davranışsal Boyut } & Correlation &, 085 \\
\cline { 2 - 3 } & Sig. (2-tailed) &, 227 \\
\hline
\end{tabular}

Tablo 4'teki korelasyon ilişkileri incelendiğindeyse örgütsel sinizmin bilişsel ve duyuşsal boyutu ile unvan arasında anlamlı ve pozitif yönde bir ilişki bulunmuştur (Sig.<0,05). Davranışsal boyutu ile unvan arasında ise ilişki anlamlı değildir (Sig.>0,05). Böylece hipotez 1.1 ve 1.2 kabul edilmiş, hipotez 1.3 ise reddedilmiştir. Bu tabloya göre bilişsel boyut (,179) unvan ile düşük seviyede bir etkileşim içerisindedir. Buna göre bilişsel boyut sinizmindeki artış unvanla az da olsa artmaktadır. Benzer olarak örgütsel sinizmin duyuşsal boyutunda unvanla az da olsa bir artış görülmektedir (,184). Bununla beraber unvan sahibi katılım bankası çalışanları davranışsal boyutta sinizm göstermemektedirler. 
Örgütsel sinizm faktörlerinin araştırmaya katılan çalışanların cinsiyetlerine göre farklılık gösterip göstermediklerini sinamak amacıyla verilere ttesti uygulanarak şu sonuçlar elde edilmiştir:

Tablo 5. Cinsiyet ile Örgütsel Sinizmin Boyutlarna İlişkin Fark Testi

\begin{tabular}{|c|c|c|c|c|c|c|c|}
\hline & Cinsiyet & $\mathbf{N}$ & Ortalama & S.S. & $\mathbf{F}$ & $\mathbf{t}$ & $\begin{array}{l}\text { Sig. } \\
\text { (2-tailed) }\end{array}$ \\
\hline \multirow{2}{*}{ Bilişsel Boyut } & Kadın & 58 & 1,9897 & 0,9369 & \multirow{2}{*}{0,02} & $-2,884$ & 0,04 \\
\hline & Erkek & 144 & 2,4167 & 0,958 & & $-2,912$ & 0,04 \\
\hline \multirow{2}{*}{ Duyuşsal Boyut } & Kadın & 58 & 1,5862 & 0,77939 & \multirow{2}{*}{1,593} & $-3,16$ & 0,02 \\
\hline & Erkek & 144 & 2,015 & 0,9073 & & $-3,37$ & 0,01 \\
\hline \multirow{2}{*}{ Davranışsal Boyut } & Kadın & 58 & 2,4425 & 1,0875 & \multirow{2}{*}{2,219} & $-2,519$ & 0,13 \\
\hline & Erkek & 144 & 2,8356 & 0,96802 & & $-2,397$ & 0,18 \\
\hline
\end{tabular}

Tablo 5'te görüldügüü üzere örgütsel sinizm faktörlerinden bilişsel boyut ile cinsiyet arasında anlamlı bir fark vardır (Sig.<0,05). Böylece hipotez 2.1 kabul edilmiştir. Örgütsel sinizm faktörlerinden duyuşsal boyut ile cinsiyet arasında anlamlı bir fark vardır (Sig.<0,05). Böylece hipotez 2.2 kabul edilmiştir. Örgütsel sinizm faktörlerinden davranışsal boyut ile cinsiyet arasında fark anlamlı değildir (Sig.>0,05). Böylece hipotez 2.3 reddedilmiştir.

\section{Bulgular ve Tartışma}

Çalışanların çalıştığı örgütlerine yönelik olumsuz davranış ve tutumları biçiminde ifade edilen örgütsel sinizm hem işletmeleri hem de çalışanlarını derinden etkilemektedir. İş hayatının her alanında yer alan Y kuşağı bireyler, sadakatsiz ve otoriter yönetimden hoşlanmamaları sebebiyle sürekli iş değiştirebilen bireyler olarak değerlendirilmektedir. Örgütlerdeki örgütsel sinizmin varlığı diğer kuşak çalışanlarından özellikleri bakımından ayrışan Y kuşağı çalışanlarını da etkilemektedir. Örgütsel sinizmin Y kuşağı çalışanlarına etkilerinin ortaya konması için yapılan bu araştırmada iş hayatında bulunan Y kuşağı çalışanlarının cinsiyet ve unvanlarının örgütsel sinizm boyutları açısından incelemesi yapılmıştır. Bu araştırma, yaşamın çeşitli noktalarında birbirleriyle ilişkili, çalışma alanları (unvan) aracılığıyla katılım bankalarının Y kuşağındaki bireyleri nasıl şekillendirdiğine ışık tutmaktadır. Aynı zamanda, yaşa dayalı nesillere mensup bireyler için cinsiyete dayalı ortak bir beklenti ve davranış kümesinin sinizme yol açıp açmadığı araştırılmıştır.

Unvan ve örgütsel sinizmi ele alan hipotezlerden hipotez 1.1 ve 1.2 kabul edilmiş, hipotez 1.3 ise reddedilmiştir. Unvan ile örgütsel sinizm arasında 
ilişkiler incelendiğinde örgütsel sinizmin bilişsel ve duyuşsal boyutu ile unvan arasında anlamlı ve pozitif yönde bir ilişki bulunmuştur. Bilişsel boyut ile pozitif yönde anlamlı bir ilişki çıkması yani $Y$ kuşağı çalışanlarının bilişsel yönden sinizm göstermesi $Y$ kuşağının teknolojiye önem vermesi bakımından anlamlıdır (Durkin, 2008). Teknolojik gelişmeleri yakından takip edemeyen veya uyum sağlayamayan işletmelerde $Y$ kuşağında sinizm oluşması beklenen bir sonuçtur. Duyuşsal boyut ise $Y$ kuşağının tepki veren sessizce kabullenmeyen özelliklerinden kaynaklanmaktadır (Chiaburu vd., 2013). Y kuşağı çalışanlarında görülen sinizm kişilik veya örgütten kaynaklanabileceği gibi Aktör-ağ kavramına dayanarak yapay özellikleri de buna neden olabilir. Buna karşın örgütsel sinizmin davranışsal boyutu ile unvan arasında ise ilişki anlamlı değildir.

Araştırma bulgularına göre katılım bankalarında çalışan Y kuşağı bireylerin unvanları arttıkça örgütsel sinizm faktörlerinden bilişsel ve duyuşsal boyutları yani kişilerin işyerlerine karşı inançları azalmakta ve duygusal kızgınlıkları artmaktadır. Buna karşın kızgınlık ve güven eksikliklerini işyerinde davranış haline getirmemekte veya yansıtmamaktadırlar. Abraham (2000)'ın belirttiğinin aksine olumsuz sinizm duyguları Türk Katılım Bankalarında sert eleştirilere dönmemiştir. Bununla beraber Chiaburu vd. (2013)'nin belirttiği gibi Y kuşağında örgütsel sinizm davranışlara yans1mamaktadır. Bu sonuç çalışmanın en önemli hususlarından birini oluşturmaktadır. Andersson ve Bateman (1997)'ın belirttiğinin aksine katılım banka çalışanları üst yönetim ve kurumlarının genelini hedef alan bir sinizm göstermemektedir. Bu insanlar yaptıkları işe ve bulundukları konuma bireysel bir bakış açısıyla bakmalarının yanında ekip çalışmasına önem verirler.

Araştırma konusu olan katılım bankaları örneği bize çalışanların tecrübe ve unvanları arttıkça örgütleriyle olan ilişkilerinde hoşnutsuzlar olduğunu buna karşın herhangi bir olumsuz davranışta bulunmadıklarını göstermiştir. Bunun sebepleri olarak unvanlarını ve işini kaybetmek istememeleri, boş vermişlik veya her ne kadar sinizme yönelik tutumlar oluşsa da diğer çalışanlara karşı olumsuz davranışlar sergilemek istememeleri olarak görülebilir. Bu tip çalışanlar için, çalışmalarına katılım önemlidir. İş harici bir zorunluluk değil, kişinin kendi yeteneklerini keşfetmenin bir yoludur. Ancak, işe kişisel katılım, aile hayatına verilen önem ile dengelenir. Bu profille eşleşen Y kuşağı için, iş ve özel hayatı ayrı ayrı düşünülmez. Çoğu, kariyerin kişisel ve aile yaşamından daha az önemli olduğunu açıkça belirtseler bile, kariyer 
ve yaşam paralel olarak gelişmektedir. Unvan ile örgütsel sinizm arasında elde edilen bu sonuçlar bize $Y$ kuşağının özelliklerinin sadece yaş ve teknolojik gelişmeler gibi çevre koşullarından belirlenmediğini göstermektedir. Aktör-ağ kuramına göre sosyal ve bu araştırmada olduğu gibi organizasyon bağlamında oluşan ağ (unvanlar) bir aktör olarak Y kuşağını da etkilemektedir.

Chiaburu vd. (2013) tarafından yapılan araştırmada cinsiyet boyutu ile örgütsel sinizm arasında anlamlı bir ilişki bulunamamıştır. Araştırmacılar bu sonuca dayanarak, demografik değişkenlerin örgütsel sinizmi öngören modellere dâhil etmeleri için güçlü teorik nedenlere ihtiyaçları olduğunu öne sürmüşlerdir. Örgütsel sinizm faktörleri ile araştırmaya katılan Y kuşağ çalışanların cinsiyetlerine göre incelemeleri bu araştırmada yapılmıştır. Bu bakımdan bu çalışma örgütsel sinizmi bir bütün olarak incelemekten ziyade örgütsel sinizmin boyutlarının cinsiyet değişkeniyle olan istatistikî ilişkilerin araştırılması açısından önemlidir. Araştırmaların kastettiği kuramsal temel ise yukarıda açıklanan Aktör-ağ kuramındadır. Bu kurama göre çalışanların (veya müşterilerin) kesin çizgilere dayanan özelliklere göre birbirlerinden ayrılmaları yerine (Miles, 2012) organizasyona yapabilecekleri katkı veya performans gibi çıtıllara göre değerlendirilmelidirler. Aksi halde araştırmamızda olduğu gibi çalışanlarda kesin ölçülere göre ayrılık sinizmin hem bilişsel hem de duygusal boyutları üzerinde anlamlı etki gösterecektir. Bir sonraki aşama ise sinizmin davranışsal boyutuna da yansıması olarak düşünülebilir.

$\mathrm{Bu}$ araştırma neticesinde bilişsel, duyuşsal ve davranışsal boyutlarda erkek katılım bankalarında çalışanlardan elde edilen aritmetik ortalamaların, kadın katılım bankaları çalışanlarından daha yüksek olduğu gözlenmiştir. Araştırma bulgularına göre kadın ve erkek Y kuşağı çalışanlar ile bilişsel ve duyuşsal boyutlar yani inanç ve duygusal deneyimler arasında anlamlı ve pozitif yönde bir fark bulunmuştur. Davranışsal boyutta ise kadın ve erkek çalışanlar için anlamlı bir fark bulunamamıştır. Literatürde örgütsel sinizmin boyutlarıyla cinsiyet arasında anlamlı ilişkilerin bulunmadığ 1 (Andersson ve Bateman, 1997; Chiaburu vd., 2013; Erdost vd., 2007; M. S. L. James, 2005; Kasalak ve Aksu, 2014; Pugh vd., 2003) araştırmalar yer almaktadır. Bununla birlikte örgütsel sinizmin boyutlariyla cinsiyet arasinda anlamlı ilişkilerin bulunduğu (Kanter ve Mirvis, 1989) araştırmalar da yer almaktadır. Cinsiyetler arasındaki farklar, erkeklerin yüksek bir gelire ve terfi olasi- 
lığına daha fazla önem vermelerinden, kadınlar ise özerkliğe ve başkalarına yardım etme olasılığına öncelik vermelerinden dolayı önemlidir.

\section{Sonuç}

Şirketler ve kamu örgütleri proaktif olarak genç yeteneklere çekiciliklerini artırmalı ve $Y$ kuşağına uygun sistemleri, yapıyı ve kültürü oluşturarak onların bağlılığını arttırmalıdır. Çünkü artan rekabet ortamında işletmelerin devamlılıklarını sağlamak için nitelikli ve yeniliklere açı işgörenlere ihtiyaçları bulunmaktadır. Y kuşağı temsilcileri, maceracı, enerjik, güven uyandırabilen, yeni deneyime açık, iletişimde kolay, alışılmadık bir durumda becerikli, ancak disiplinsiz, çatışan, kararsız olarak karakterize edilebilir(V. Pishchik ve Miroshnichenko, 2020). İşgörenler ise kendilerini anlayan, beklentilerini karşılayan, iletişime açı işveren ve yöneticilere ihtiyaç duymak-

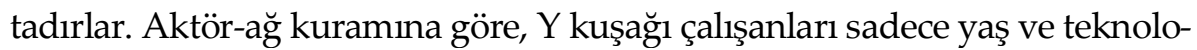
jinin getirdiği değil organizasyondaki bağlamsal etkilere göre de farklllıklar sergilemektedir. Çünkü kurama göre sadece yaş gibi doğal sebepler değil organizasyon içerisinde yapay olarak oluşan sistemlerde bireylerde kuşak oluşturma yönünde ittifaklar oluşturmaktadır.

Türkiye'nin 2017 yılı Adrese Dayalı Nüfus Kayıt Sistemi (ADNKS) nüfus sayım sonuçları baz alındığında \%30,11 ile nüfusta en yüksek orana $Y$ kuşağı sahiptir. Bu oranın iş yaşamında da olduğu kabul edilirse; etkisini sürekli arttıran Y kuşağı çalışanlar örgütsel sinizmden en azından sayı bakımından daha fazla etkilenmektedir. Bu araştırmanın temel amacı da örgütsel sinizmin Y kuşağı çalışanlarına etkileri ortaya konulmasıdır. Bu amaç doğrultusunda oluşturulan hipotezleri test etmek için katılım bankalarında araştırmaya katılan Y kuşağı çalışanların örgütsel sinizm etkilerini belirlemeye yönelik anket uygulanmıştır. Sinizm, bu çalışmada bilişsel, duyuşsal ve davranışsal olarak üç olumsuz işgören tutumu şeklinde incelenmiştir (Andersson ve Bateman, 1997; Stanley vd., 2005). Bu boyutların, Y kuşağını tanımlayan ve bazıları doğal sebeplerle oluşmuş farklılıkları ve benzerliklerinin üzerindeki etkilerini incelemek literatüre önemli katkılar sağlayacaktır.

Çalışmamı, Y kuşağındaki sinizmin unsurların bağlama bağlı olabileceğini göstermektedir (örneğin, statü). Ek olarak, farklı yaş aralıklarına sahip bireysel seviye tercihlerindeki olası farklılıklar, boylamsal bir çalışma kullanılarak araştırılmalıdır. Araştırmamızın sonuçlarına göre, Y kuşağının örgüt 
içerisindeki kariyer planlarını algılamada ve buna tepkilerinde farklı olduklarını göstermektedir. Bu, maliyet odaklı bir strateji uygulayan ve verimliliği artırmak için yoğun baskı altında çalışanlardan oluşan örgütlerde bir sorun haline gelebilir.

İşletmeler için yapılması gerekenler bu tutumların sebeplerini araştırmak cinsiyet, unvan ve statü konusunda katılımcllı gibi modern yönetim tekniklerini kullanmak olabilir. Sinizm temel düşüncesinden birisi içerisinde bulunulan sosyal yapıya karşı koymaktır (Schutijser, 2017). Bununla beraber, bu karşı koyma tüm sosyal yapıya değil, sinizm davranışı gösteren çalışanlarda bireyi kısıtladığı ya da bir şeylerden yoksun bıraktığı yönlere doğru olmaktadır (Diogenes Laertius ve Mensch, 2018). Yani işletmeler Y kuşağının kendilerini kısıtlayacağı düşündüğü engelleri ve objeleri kaldırarak bu neslin iş yaşamında daha verimli olmasını sağlayabilir. İlk olarak, kurum $Y$ kuşağı için sosyal medya ile ilgili daha fazla görev verebilir. Başka bir deyişle, sosyal medya uygulamalarının kısıtlanmak yerine, hem onlara hem de işletmenin amaçlarına yönelik şekilde kullanılması sağlanabilir. İkincisi, Y kuşağı zamanlarını paralarına karşı vermeyi tercih ettikleri için, işletmeler, işgücünde $Y$ kuşağı üyelerine işin anlamını ve önemi daha iyi anlatmak durumundadırlar.

İş yaşamında sinizm gösteren bireylerin diğer bir önemli özelliği ise, içinde bulunduğu yapıyla mücadele etmek değil, gerektiğinde bir örnek te oluşturacak şekilde kendi bireysel yaşantısını sürdürebilmektir (Schutijser, 2017). Özellikle bu bakımdan, salgınla birlikte oluşan uzaktan çalışma, esnek çalışma yöntemleriyle başarılı $\mathrm{Y}$ kuşağı çalışanlarına en üst düzeyde performans gösterecekleri şekilde çalışma imkânları sağlanabilir. Çünkü çalışma $Y$ kuşağının hayatında önemli bir yer tutmakla beraber, sinizm şeklinde davranışlar göstermemesi için bu çalışma ortamının $\mathrm{Y}$ kuşağı bireyinin gelişimine uygun ve doğal olmayan şekillerden uzak olması gerekir. Unvanın, sinizm üzerindeki etkileri düşünüldüğünde yönetim bilişim sistemleri uygulamaların işletmede yaygınlaştırılması, karar verme mekanizmalarının daha rasyonel olması, yükselmelerin teknolojik gelişmeleri dikkate alacak şekilde şeffaf olarak yapılması, sinizm davranışlarının engellenmesinde $Y$ kuşağ 1 için önemli olabilir.

Bu sonuçlar yöneticiler için iki ucu keskin bir kılıçtır. Bir yandan, eğer örgütler çalışan sinizminin yükselişinin farkında değilse, yan etkilerinin diğer örgütsel aktörlere yayılabileceğini ve aynı zamanda çoklu sorunlarıyla 
başa çıkmayı zorlaştırabileceğini göstermektedir. İşletmeler için önemli bir diğer hususta sinizmin daha başlamadan önlenmesinin gerekli olduğudur. Van Dierendonck vd. (1998) tarafından yapılan çalışmaya göre eğitim ne yazık ki sinizmi etkilememektedir.

Y kuşağı çalışanlarında örgütsel sinizm adlı bu çalışma alanyazında hem örgütsel sinizm hem de $Y$ kuşağı çalışanları üzerine yapılan çalışmaların yetersiz olması sebebiyle bu yöndeki eksikliği giderme ve alan yazına katkı sağlama bakımından değerli görülmektedir. Tek başına önemli bir sorun olan örgütsel sinizm günümüz çalışma hayatında farklı özelliklere sahip Y kuşağı bireylerde ortaya çıktığında işletmeler için çok daha büyük sorunlara yol açabilmektedir. Bu çalışmanın Y kuşağı çalışanlarında örgütsel sinizmin ele alınması yönünden özgün olması sebebiyle önemli olduğu düşünülmektedir. Güncel alan yazına katkısı bakımından Türkiye'de faaliyet gösteren katılım bankalarında çalışan $Y$ kuşağı bireylerin örgütsel sinizmin boyutları olan bilişsel, duyuşsal, davranışsal boyutlarıyla unvan ve cinsiyete göre ilişkilerine dikkat çekilerek hem mevcut çalışmalara katkı sunulmuş hem de bundan sonra yapılacak benzer araştırmalara katkı sağlamaya yönelik bir adım atılmıştır.

Katılım bankalarının Y kuşağı çalışanlarına yönelik yapılan bu araştırmanın sınırlılıkları şunlardır:

1. Bu araştırma, Türkiye'de faaliyet gösteren Albaraka Türk, Kuveyt Türk, Türkiye Finans, Vakıf ve Ziraat Katılım Bankaları Anonim Şirketlerinin ankete katılan Y kuşağı çalışanlarının görüşleri ile sınırlıdır.

2. Bu araştırmayla Türkiye'de faaliyet gösteren katılım bankalarında çallşan Y kuşağı bireylerin deneyimledikleri örgütsel sinizmin bilişsel, duyuşsal, davranışsal boyutlarıyla unvan ve cinsiyet dışındaki diğer değişkenler araştırmanın kapsamı dişında tutulmuştur.

3. Anketler e-posta yoluyla gönderilmiş olup bu araştırma ankete cevap verenler ile sinurlıdir.

4. Ankete katılan bireylerin kendileri için doğru olan seçenekler yerine diğer seçenekleri cevap olarak işaretleme ihtimalleri araştırmanın sınırl1lığı olarak kabul edilebilir.

5. Bu araştırma ile ulaşılan sonuçlar, sadece araştırmanın evrenini oluşturan katılım bankalarında çalışan Y kuşağı bireyler için genellenebilir.

6. Bu araştırma, veri toplama aracından elde edilen veriler ile sınırlıdır. 
Gelecekte yapılacak çalışmalarda sadece katılım bankaları değil diğer bankalar da mevcut durumun araştırılması ve karşılaştırılması literatüre ve uygulamaya önemli katkılar sağlayabilir. Bununla birlikte iş yaşamında yerlerini almaya başlayan ve $\mathrm{Y}$ kuşağı ile birlikte çalışacak olan $\mathrm{Z}$ kuşağ bireyler hakkında araştırmalar yapılarak bu alana katkı sağlanabilir. 


\title{
EXTENDED ABSTRACT
}

\section{Organizational Cynicism from Generation Y Perspective}

\author{
$*$ \\ Haydar Arslan - Korhan Arun \\ Tekirdag Namik Kemal University
}

Organizational cynicism which is an important problem on its own can cause much bigger problems for organizations when emerges in generation " $Y$ " with different characteristics in today's business life. This research aims to contribute to the literature by revealing the interaction of organizational cynicism for $\mathrm{Y}$ generation employees. This study of organizational cynicism on generation " $Y$ " employees is thought to be prominent in terms of the insufficiency of similar studies, and the findings obtained. The contribution of the study to the current literature is in two significant ways. First, the relations between the dimensions of organizational cynicism (cognitive, affective, and behavioral) and title and gender variables of employees of Generation $Y$ individuals of participating banks operating in Turkey were examined for the first time. Secondly, a step has been taken to contribute to be similar research to be conducted from this point on.

Organizational cynicism is expressed as the negative behaviors and attitudes of the employees in the organizations they work for. Cynicism is generally considered in three dimensions in the literature. These dimensions are the cognitive (belief) dimension, affective (emotion) dimension, and behavioral (behavioral) dimension. Cognitive (belief) Dimensions of organizational cynicism expressed the belief that businesses are not mutually complementary and that employees do not perceive the business honestly. This type of emotions, which are generally expressed negatively by individuals in the organization, defines the affective dimension. The behavioral Dimension, on the other hand, is the situation where people's beliefs and thoughts affect their behavior (Arslan, 2019; Pelit \& Pelit, 2014). Generation Y is defined as individuals born between 1981-2000, although there is no clear consensus between their birth dates. Generation Y, which is the latest in today's business world and is more than the other generation individuals in terms of a num- 
ber, has shown its effects all over the world, forcing many organizations to change their way of doing business.

Cynicism is not just disappointment, despair, and delusion. It can be defined as a special attitude based on distrust towards a person, group, ideology, social group, or institution. Generation $Y$ itself has taken part in a period of technology and rapid change, and naturally; they have carried these characteristics to business life. On the other hand, the fact that the technology, management structure, and even the perceptions of the enterprise on the network are different by the $Y$ generation actors may result in these people acting from a cynicism perspective in the organizations. Although it has been stated that individuals with cynicism have a low level of satisfaction, criticize, have an interest in them and have a negative point of view, their effect on generations has not been studied.

This generation is naturally formed according to the actor-network theory. This study was tested by the questionnaire method, whether the technologyorganization-individual interaction, which is also stated in the theory, is meaningful to title and gender variables in cynicism dimensions. The research universe is formed of Generation " $Y$ " employees of participation banks in Turkey. In this context, a questionnaire was distributed to approximately 500 employees using the simple random method, and 215 were returned; 202 questionnaires were included in the analysis after the erroneous questionnaires were removed. Findings are obtained by factor analysis, t-test, and correlation analysis. It was found that the cynicism dimensions of the generation $\mathrm{Y}$ individuals working in the participation banks are statistically significantly different according to demographic characteristics of income, title, and gender variables. According to the findings of the research, as the titles of generation $Y$ employees, working in participation banks increase, their cognitive and affective dimensions, which are among the organizational cynicism factors, increase. In other words, as titles increase, people's beliefs about their workplace decrease, and their emotional anger increases. However, they do not turn their anger and lack of trust in behavior or reflect them in the workplace. The example of participation banks, which is the subject of this research, showed us that as the experience and titles of the employees increased, they were dissatisfied in their relations with their organizations, but they did not take any negative behavior. The reasons for this can be seen as not wanting to lose their title and job, neglect, or not wanting to behave negatively 
towards other employees, even though there are attitudes towards cynicism. The analyzes also show that there is a significant difference between the organizational cynicism factors, cognitive dimension, and gender. Furthermore, there is an important difference between the affective dimension and gender, which are among organizational cynicism factors. Among organizational cynicism factors, the difference between behavioral dimension and gender is not significant. In a nutshell, when the gender variable is analyzed as an independent variable, although employees display different cynicism attitudes, organizational cynicism behaviors are the same. To put it more clearly, even though there are differences based on gender in the causes of organizational cynicism, cynicism behaviors are similar to an outcome. As a result of these findings, it is seen that contrary to what is perceived in the literature; generation $\mathrm{Y}$ employees are exposed to cynicism not only in terms of age but also in title and gender dimensions.

These results are a double-edged sword for managers. On the one hand, it shows that if organizations are unaware of the rise of employee cynicism, its side effects can spread to other organizational variables and at the same time make it difficult to cope with their multiple problems. Another important issue for businesses is that cynicism must be prevented before it even begins. According to the study conducted by Van Dierendonck et al. (1998), education, unfortunately, does not change cynicism. As a result, preventing measures are more important than the remedy. Limitations of this study are as follows: This research, depending on surveys of Generation Y employees of the Participation Banks operating in Turkey, is limited to the opinions of the self-perceptions. Secondly, Individuals participating in the questionnaire may have marked the correct options according to the organization instead of the options that are right for them.

In future studies, researching and comparing the current situation not only for participation banks but also for other banks can make significant contributions to the literature and practice. Besides, contribution to this field can be made about the individuals of Generation $\mathrm{Z}$ who have started to take their place in business life and will work with the generation $\mathrm{Y}$.

\section{Kaynakça / References}

Abraham, R. (2000). Organizational cynicism: Bases and consequences. Genetic, Social, and General Psychology Monographs, 126(3), 269. 
Ajzen, I. (2001). Nature and operation of attitudes. Annual Review Of Psychology, 52(1), 27-58. https://doi.org/10/cqp7jm

Akar, H. (2019). A Meta-analytic review on the causes and consequences of organizational cynicism. International Online Journal of Educational Sciences, 11(2). https://doi.org/10/gf744m

Altuntaş, B. (2017). Y kuşağının mobil öğrenme uygulama tercihini etkileyen faktörlerin incelenmesi. İnsan ve Toplum Bilimleri Araştrmalarn Dergisi, 6(6), 89-104. https://doi.org/10.15869/itobiad.356544

Andersson, L. M. (1996). Employee cynicism: An examination using a contract violation framework. Human Relations, 49(11), 1395-1418. https://doi.org/10/fhhgdg

Andersson, L. M., ve Bateman, T. S. (1997). Cynicism in the workplace: Some causes and effects. Journal of Organizational Behavior: The International Journal of Industrial, Occupational and Organizational Psychology and Behavior, 18(5), 449-469.

Arslan, H. (2019). Örgütsel sinizmin Y kuşă̆ı çalışanlarnna etkileri: Katılım bankalan örneği. Yüsek Lisans Tezi. Tekirdağ Namık Kemal Üniversitesi.

Arun, K., ve Arslan, H. (2019). Y kuşağı çalışanları açısından örgütsel sinizm. 21. International congress of management economy and policy 2019 autumn proceedings book, 477 .

B. Valentine, D., ve L. Powers, T. (2013). Generation Y values and lifestyle segments. Journal of Consumer Marketing, 30(7), 597-606. https://doi.org/10.1108/JCM-072013-0650

Baykal, E. (2019). Participation banks: A suitable environment for workplace spirituality. Mevzu Sosyal Bilimler Dergisi, 2, 43-63. https://doi.org/10.5281/ZENODO.3463824

Berkup, S. B. (2014). Working with generations $x$ and $y$ in generation $z$ period: Management Of Different Generations In Business Life. Mediterranean Journal of Social Sciences. 5(19). https://doi.org/10/ggf3tp

Biggs, A., Brough, P., ve Drummond, S. (2017). Lazarus and Folkman's psychological stress and coping theory. The Handbook of Stress and Health (s. 349-364). John Wiley ve Sons, Ltd. https://doi.org/10.1002/9781118993811.ch21

Blumer, H. (2009). Symbolic interactionism: Perspective and method (Nachdr.). Univ. of California Press.

Bommer, W. H., Rich, G. A., ve Rubin, R. S. (2005). Changing attitudes about change: Longitudinal effects of transformational leader behavior on employee cynicism about organizational change. Journal of Organizational Behavior, 26(7), 733-753. https://doi.org/10/c45ftw 
Bordua, D. J. (1968). Arthur Niederhoffer. Behind the Shield: The Police in Urban Society. Pp. vi, 253. Garden City, N.Y.: Double-day, 1967. The ANNALS of the American Academy of Political and Social Science, 377(1), 202-203. https://doi.org/10/bzqwn5

Cennamo, L., ve Gardner, D. (2011). Generational differences in work values, outcomes and person-organisation values fit. IEEE Engineering Management Review, 39(2), 24-36.

Charters, S., Velikova, N., Ritchie, C., Fountain, J., Thach, L., Dodd, T. H., Fish, N., Herbst, F., ve Terblanche, N. (2011). Generation y and sparkling wines: A cross-cultural perspective. International Journal of Wine Business Research, 23(2), 161-175. https://doi.org/10/b8d7wh

Chiaburu, D. S., Oh, I.-S., Berry, C. M., Li, N., ve Gardner, R. G. (2011). The five-factor model of personality traits and organizational citizenship behaviors: A metaanalysis. Journal of Applied Psychology, 96(6), 1140-1166. https://doi.org/10/fnfd2q

Chiaburu, D. S., Peng, A. C., Oh, I.-S., Banks, G. C., ve Lomeli, L. C. (2013). Antecedents and consequences of employee organizational cynicism: A metaanalysis. Journal of Vocational Behavior, 83(2), 181-197. https://doi.org/10/gcz6zv

Cook, W. W., ve Medley, D. M. (1954). Proposed hostility and Pharisaic-virtue scales for the MMPI. Journal of Applied Psychology, 38(6), 414-418. https://doi.org/10/bcgxx2

Costa, P. T., Zonderman, A. B., McCrae, R. R., ve Williams, R. B. (1986). Cynicism and paranoid alienation in the Cook and Medley HO Scale.: Psychosomatic Medicine, 48(3), 283-285. https://doi.org/10/gf927f

Cox, T. (1994). Cultural diversity in organizations: Theory, research and practice. BerrettKoehler Publishers.

Cutler, I. (2000). The cynical manager. Management Learning, 31(3), 295-312. https://doi.org/10/chtdqb

De Hauw, S., ve De Vos, A. (2010). Millennials' career perspective and psychological contract expectations: Does the recession lead to lowered expectations? Journal of Business and Psychology, 25(2), 293-302. https://doi.org/10/ct65dm

Dean, J. W., Brandes, P., ve Dharwadkar, R. (1998). Organizational cynicism. The Academy of Management Review, 23(2), 341. https://doi.org/10.2307/259378

Diogenes Laertius, ve Mensch, P. (2018). Lives of the eminent philosophers. Oxford University Press.

Durkin, D. (2008). Youth movement. Communication World, 25(2), 23. 
Edmunds, J., ve Turner, B. (2006). Global Generations: Social Change in the Twentieth Century. The British Journal of Sociology, 56, 559-577. https://doi.org/10/bhrb6r

Erdost, E. H., Karacaoğlu, K., ve Reyhanoğlu, M. (2007). Örgütsel sinizm kavramı ve ilgili ölçeklerin Türkiye'deki bir firmada test edilmesi. Ulusal Yönetim ve Organizasyon Kongresi, 514-524.

Fauzan, R. (2019). Upgrading at work: Employee disposition and cynicism about organizational changes. International Journal of Organizational Analysis, 28(3), 677-697.https://doi.org/10/ggwsij

Fenwick, T. J., ve Edwards, R. (2010). Actor-network theory in education (1st ed). Routledge.

Goldner, F. H., Ritti, R. R., ve Ference, T. P. (1977). The production of cynical knowledge in organizations. American Sociological Review, 42(4), 539. https://doi.org/10/b8c5xz

Hassi, A., Foutouh, N., ve Ramid, S. (2015). Employee perception of diversity in Morocco: Empirical insights. Journal of Global Responsibility, 6(1), 4-18. https://doi.org/10/ggwr9m

Hickman, M. J., Piquero, N. L., ve Piquero, A. R. (2004). The validity of Niederhoffer's cynicism scale. Journal of Criminal Justice, 32(1), 1-13. https://doi.org/10/fm229t

Horváthová, P., Mikušová, M., ve Kashi, K. (2019). Evaluation of the employees' engagement factors importance methodology including generation Y. Ekonomska Istraživanja, 32(1), 3895-3917.https://doi.org/10/gg354v

Hulin, C. L., ve Judge, T. A. (2003). Job Attitudes. In I. B. Weiner (Ed.), Handbook of Psychology (p.1211). John Wiley ve Sons, Inc. https://doi.org/10.1002/0471264385.wei1211

Humphrey, N., Bartolo, P., Ale, P., Calleja, C., Hofsaess, T., Janikova, V., Lous, A. M., Vilkiene, V., ve Wetso, G.-M. (2006). Understanding and responding to diversity in the primary classroom: An international study. European Journal of Teacher Education, 29(3), 305-318. https://doi.org/10.1080/02619760600795122

Hurst, J. L., ve Good, L. K. (2009). Generation Y and career choice: The impact of retail career perceptions, expectations and entitlement perceptions. Career Development International, 14(6), 570-593. https://doi.org/10/dbk7q6

Israel, G. D. (2013). Determining sample size 1. University of Florida, 1-5.

James, J., Mckechnie, S., ve Swanberg, J. (2011). Predicting employee engagement in an age-diverse retail workforce. Journal of Organizational Behavior, 32, 173-196. https://doi.org/10/dzgqvf 
James, M. S. L. (2005). Antecedents and consequences of cynicism in organizations: An examination of the potential positive and negative effects on school systems. http://fsu.digital.flvc.org/islandora/object/fsu\%3A181909/

Johnson, J. L., ve O'Leary-Kelly, A. M. (2003). The effects of psychological contract breach and organizational cynicism: Not all social exchange violations are created equal. Journal of Organizational Behavior, 24(5), 627-647. https://doi.org/10/bbm46d

Joshi, A., Dencker, J. C., ve Franz, G. (2011). Generations in organizations. Research in Organizational Behavior, 31, 177-205. https://doi.org/10/dssh55

Kalağan, G., ve Aksu, M. B. (2010). Organizational cynicism of the research assistants: A Case of Akdeniz University. Procedia - Social and Behavioral Sciences, 2(2), 4820-4825. https://doi.org/10/cjvgig

Kanbur, E., ve Canbek, M. (2020). Örgütsel sinizmin işten ayrilma niyetine etkisinde yaşın düzenleyici rolünün. Journal of Business Research - Turk, 11(3), 149-1502. https://doi.org/10/ggwsh4

Kanter, D. L., ve Mirvis, P. H. (1989). The cynical Americans: Living and working in an age of discontent and disillusion (1st ed). Jossey-Bass.

Kasalak, G., ve Aksu, M. (2014). Araştırma görevlilerinin algladıkları örgütsel desteğin örgütsel sinizm ile ilişkisi. Kuram ve Uygulamada Eğitim Bilimleri, 14(1), 115-133.

Kim, S., Jung, K., Noh, G., ve Kang, L. K. (2019). What makes employees cynical in public organizations? Antecedents of organizational cynicism. Social Behavior and Personality: An International Journal, 47(6), 1-10. https://doi.org/10/ggwr68

Krahn, H. J., ve Galambos, N. L. (2014). Work values and beliefs of 'Generation X' and 'Generation Y. Journal of Youth Studies, 17(1), 92-112. https://doi.org/10/gfwdtj

Kultalahti, S., ve Viitala, R. (2015). Generation Y - challenging clients for HRM? Journal of Managerial Psychology, 30(1), 101-114. https://doi.org/10/f639k3

Kupperschmidt, B. R. (2000). Multigeneration employees: Strategies for effective management. The Health Care Manager, 19(1), 65-76. https://doi.org/10/zmf

Latour, B. (1999). On Recalling Ant. The Sociological Review, 47(1_suppl), 15-25. https://doi.org/10/t3m

Lynch, P. D., Eisenberger, R., ve Armeli, S. (1999). Perceived organizational support: Inferior versus superior performance by wary employees. Journal of Applied Psychology, 84(4), 467-483. https://doi.org/10/fgpmpz

Macky, K., Gardner, D., Forsyth, S., ve Cennamo, L. (2008). Generational differences in work values, outcomes and person-organisation values fit. Journal of Managerial Psychology. 
Mannheim, K. (1970). The problem of generations. Psychoanalytic Review, 57(3), 378404.

Mannheim, K., Mannheim, K., Kecskemeti, P., Mannheim, K., ve Mannheim, K. (1972). Essays on the sociology of knowledge. Routledge and Kegan Paul.

Matson, W. I. (2000). A new history of philosophy (2nd ed). Harcourt College Publishers.

Mayer, K. U., ve Tuma, N. B. (Eds.). (1990). Event history analysis in life course research. University of Wisconsin Press.

McCourt, D. M. (2012). The "problem of generations" Revisited: Karl Mannheim and the sociology of knowledge in international relations. B. J. Steele ve J. M. Acuff (Eds.), Theory and Application of the "Generation" in International Relations and Politics içinde (s. 47-70). Palgrave Macmillan US. https://doi.org/10.1057/9781137011565_3

Méda, D., ve Vendramin, P. (2017). The meaning of work through the prism of the generations. D. Méda ve P. Vendramin, Reinventing Work in Europe içinde (s. 145-175). Springer International Publishing. https://doi.org/10.1007/978-3-31939525-8_5

Miles, J. A. (2012). Management and organization theory: A Jossey-Bass reader (1. ed). Jossey-Bass.

Morf, M., Bakker, A. B., ve Feierabend, A. (2019). Bankers closing idiosyncratic deals: Implications for organisational cynicism. Human Resource Management Journal, 29(4), 585-599. https://doi.org/10/gg35jn

Morton, L. P. (2002). Targeting generation Y. Public Relations Quarterly, 47(2), 46.

Moscardo, G., ve Benckendorff, P. (2010). Mythbusting: Generation Y and Travel. Tourism and Generation $Y$.

Munir, Y., Ghafoor, M. M., ve Rasli, A. M. D. (2018). Perception of ethical climate and turnover intention among nursing staff: Does organizational cynicism mediate? International Journal of Human Rights in Healthcare, 11(5), 319-332. https://doi.org/10/ggxf9h

Naseer, S., Raja, U., Syed, F., ve Baig, M. U. A. (2020). When and why organizational cynicism leads to CWBs. Personnel Review, ahead-of-print(ahead-of-print). https://doi.org/10.1108/PR-09-2019-0480

Naus, A. J. A. M. (2007). Organizational Cynicism: On the nature, antecedents, and consequences of employee cynicism toward the employing organization [PhD Thesis]. Maastricht University. 
Nazarian, A., Soares, A., ve Lottermoser, B. (2017). Inherited organizational performance? The perceptions of generation $\mathrm{Y}$ on the influence of leadership styles. Leadership ve Organization Development Journal, 38(8), 1078-1094. https://doi.org/10.1108/LODJ-05-2016-0119

Niederhoffer, A. (1967). Behind the shield: The police in urban society. Anchor Books.

Parry, E., ve Urwin, P. (2011). Generational differences in work values: A review of theory and evidence. International Journal of Management Reviews, 13. https://doi.org/10/bbvirn

Pelit, N., ve Pelit, E. (2014). Örgütlerde kanser yapıc iki başat faktör mobbing ve örtüsel sinizm: teori süreç ve örgütlere yansımaları. Detay Yayıncllk.

Pfeffer, J. (1981). Management as symbolic action: The creation and maintenance of organizational paradigm. Research in Organizational Behavior, 3, 1-52.

Pilcher, J. (1994). Mannheim's sociology of generations: An undervalued legacy. The British Journal of Sociology, 45(3), 481-495. JSTOR. https://doi.org/10/bntvdk

Pishchik, V. I. (2018). Typological and identifying characteristics of generations. Российский Психологический Журнал, 15(2), 215-236. https://doi.org/10/ggxf98

Pishchik, V., ve Miroshnichenko, N. (2020). Special features of social capital of generation $\mathrm{x}$ and $\mathrm{y}$ in the network space. DEStech Transactions on Social Science, Education and Human Science, icesd. https://doi.org/10/ggxghc

Plummer, J. T. (1974). The concept and application of life style segmentation: The combination of two useful concepts provides a unique and important view of the market. Journal of Marketing, 38(1), 33-37.

Pugh, S. D., Skarlicki, D. P., ve Passell, B. S. (2003). After the fall: Layoff victims' trust and cynicism in re-employment. Journal of Occupational and Organizational Psychology, 76(2), 201-212. https://doi.org/10/btfdgs

Regoli, B., Crank, J. P., ve Rivera, G. F. (1990). The construction and implementation of an alternative measure of police cynicism. Criminal Justice and Behavior, 17(4), 395-409. https://doi.org/10/ft4jdk

Reisenwitz, T. H., ve Iyer, R. (2009). Differences in generation x and generation y: Implications For The Organization And Marketers. Marketing Management Journal, 19(2).

Roth, G. (2017). Persönlichkeit, entscheidung und verhalten: Warum es so schwierig ist, sich und andere zu ändern (12. Auflage). Klett-Cotta.

Schmidt, C., Möller, J., Schmidt, K., Gerbershagen, M., Wappler, F., Limmroth, V., Padosch, S., ve Bauer, M. (2011). Generation Y. Der Anaesthesist, 60(6), 517. 
Schmidt, K., Meyer, J., Liebeneiner, J., Schmidt, C. E., ve Hüttenbrink, K. B. (2012). Generation y in der hno: Führung einer neuen Generation von Ärzten. HNO, 60(11), 993-1002. https://doi.org/10/ggwr7v

Schulenburg, N. (2016). Führung einer neuen generation. Springer Fachmedien Wiesbaden. https://doi.org/10.1007/978-3-658-07204-9

Schutijser, D. (2017). Cynicism as a way of life: From the Classical Cynic to a New Cynicism. Akropolis, 1. https://doi.org/10/gg359v

Scott, K. A., ve Zweig, D. (2016). Understanding and mitigating cynicism in the workplace. Journal of Managerial Psychology, 31(2), 552-569. https://doi.org/10/f8jjmz

Scott, K. A., ve Zweig, D. (2020). The cynical subordinate: Exploring organizational cynicism, LMX, and loyalty. Personnel Review, ahead-of-print(ahead-of-print). https://doi.org/10/ggwsg2

Şen, C. (2018). The impact of psychological capital on job performance and cynicism: The moderator effect of cultural tightness-looseness. Doctoral Dissertation. Ankara Başkent Üniversitesi.

Şen, C. (2019). Çok kültürlü iş ortamlarında entegrasyon mekanizmaları: Uluslararası barış güçleri üzerine nitel bir araştırma. Savunma Bilimleri Dergisi, 1-26. https://doi.org/10/gg38fv

Shelton, C. J. (1993). A construct validity study of the Cynicism Scale of the MMPI-2 [Ph.D.]. https://search.proquest.com/docview/304112760/abstract/BFE8989225AD4F4 $5 \mathrm{PQ} / 1$

Solnet, D., ve Hood, A. (2008). Generation y as hospitality employees: Framing a Research Agenda. Journal of Hospitality and Tourism Management, 15(1), 59-68. https://doi.org/10/gf82n8

Sonnenberg, M., Koene, B., ve Paauwe, J. (2011). Balancing HRM: the psychological contract of employees. Personnel Review. https://doi.org/10/c8xdcr

Spencer, D. C., Ricciardelli, R., Ballucci, D., ve Walby, K. (2019). Cynicism, dirty work, and policing sex crimes. Policing: An International Journal, 43(1), 151-165. https://doi.org/10/ggwsjc

Stanley, D. J., Meyer, J. P., ve Topolnytsky, L. (2005). Employee cynicism and resistance to organizational change. Journal of Business and Psychology, 19(4), 429-459. https://doi.org/10/b9w574

Sturges, J., Guest, D., Conway, N., ve Davey, K. M. (2002). A longitudinal study of the relationship between career management and organizational commitment among graduates in the first ten years at work. Journal of Organizational Behavior, 23(6), 731-748. https://doi.org/10/fvw74n 
Türkiye Katılım Bankaları Birliği.[TKBB].(2020).Veri Seti https://www.tkbb.org.tr/veri-seti Tokgöz, N., ve Yılmaz, H. (2008). Örgütsel sinisizm: Eskişehir ve Alanya'daki otel işletmelerinde bir uygulama.

Van Dierendonck, D., Schaufeli, W. B., ve Buunk, B. P. (1998). The evaluation of an individual burnout intervention program: The role of inequity and social support. Journal of Applied Psychology, 83(3), 392-407. https://doi.org/10/bfcqvc

Vendramin, P. (Ed.). (2010). Generations at work and social cohesion in Europe. P.I.E. Peter Lang.

V.i, P. (2011). Generations: Socio-Psychological Analysis of Mentality. Social Psychology and Society.https://psyjournals.ru/en/social_psy/2011/n2/44357.shtml

Wanous, J. P., Reichers, A. E., ve Austin, J. T. (2000). Cynicism about organizational change: Measurement, antecedents, and correlates. Group ve Organization Management, 25(2), 132-153. https://doi.org/10/cwzc67

Wessells, A. T. (2007). Reassembling the social: An introduction to actor-networktheory by Bruno Latour: A review of: " Reassembling the social: An Introduction to Actor-Network-Theory . Bruno Latour. New York: Oxford University Press, 2005. 312 pages. ISBN: 0199256047." International Public Management Journal, 10(3), 351-356. https://doi.org/10/c47xws

Wey Smola, K., ve Sutton, C. D. (2002). Generational differences: Revisiting generational work values for the new millennium. Journal of Organizational Behazior, 23(4), 363-382. https://doi.org/10.1002/job.147

Whitener, E. M., Brodt, S. E., ve Korsgaard, M. A. (2012). Understanding the Relationship between Cynicism and Trust.

Williams, G. (2020). Management Millennialism: Designing the New Generation of Employee. Work, Employment and Society, 34(3), 371-387. https://doi.org/10/gg38br

Wohl, R. (1981). The generation of 1914. Harvard University Press.

Zhang, Q., Sun, S., Zheng, X., ve Liu, W. (2019). The role of cynicism and personal traits in the organizational political climate and sustainable creativity. Sustainability, 11(1), 257. https://doi.org/10/ggwssd

\section{Kaynakça Bilgisi / Citation Information}

Arslan, H. ve Arun, K. (2020). Y kuşağ1 çalışanlarında örgütsel sinizm: Görgül bir çalışma. OPUS-Uluslararası Toplum Araştırmaları Dergisi, 16(32), 4688-4722. DOI: 10.26466/opus.741151 